\title{
Chirac drops university reform bill to buy time
}

French Prime Minister Jacques Chirac appeared on national television on Monday morning to save his government. He announced the abandonment of the university reform bill that had led to demonstrations, then riots and finally the death of a student in Paris on Friday evening. Chirac's fragile coalition of right-wing parties was in danger of breaking up under the pressure of these events. Alain Devaquet, the universities and research minister, handed in his resignation on Friday night after the education minister René Monory announced, also on television, that he was to take over the steering of the bill; on Sunday, Alain Madelin, industry minister, said that the reforms "were not worth a life"; and others had begun to distance themselves from an administration that was rapidly being tainted as "anti-youth"

Just eight days earlier, Chirac had offered concessions to students on the three key points at issue - selection on university entry, local university degrees (they are at present national) and an increase in entry fees, which would vary from university to university But these proved not to be enough for student leaders who demanded complete renunciation of the whole bill.

Some, though, believe that the battle was won not by the students - who claimed to be apolitical in their protest but by more violent elements that began to attach themselves to the previously peaceful demonstrations.

Where this debacle leaves the French universities and research is by no means clear. Devaquet had spoken of the "irony" of being tarred by students as an extremist, when his whole effort has been to tone down some of the more extreme libertarian elements of the bill that emerged from the right wing of Chirac's party and while he has successfully defended against that same wing other academic institutions such as the national research centre (CNRS). His resignation leaves a gap which Chirac will find difficult to fill.

But is Chirac's attempt at university reform dead?. Chirac is an authoritarian (if realistic) prime minister, who said only a few days ago that he had been elected to "govern", so a new bill may yet emerge once tempers are cooled.

As to why the French students - and high-school children - were so determined to resist selection, and increasing university autonomy, the answers are more social and psychological than political.

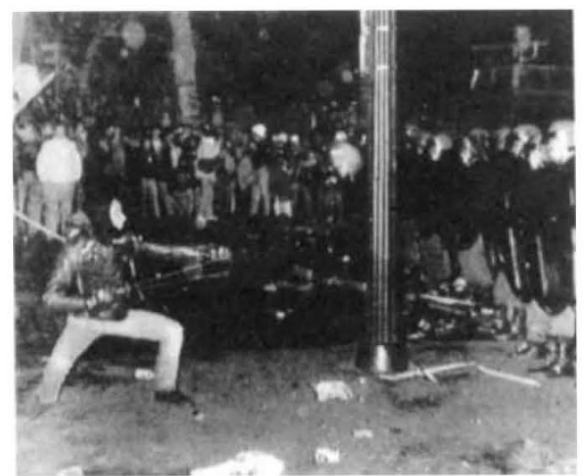

5 December: a demonstrator with sling faces riot police.

Selection does operate in French universities already, but it bites late on entry to the second and third years. It is made by university staff on new grounds; so a schoolboy or girl who has failed to make good progress at the very authoritarian French schools has a second chance in the first year of university (provided he or she passes the school-leaving baccalaureat). Preuniversity selection means denying that second chance; and that can mean the dole queue.

The previous government planned to increase the entry to the first year of university, and making it explicitly a year of 'orientation' that could lead to jobs or other educational institutions as well as onwards in the university; but it failed to provide the resources to accomplish the task and created resentment among university staff. This government attempted to please that staff. But it forgot about the students.
Robert Walgate

\section{Vera Rich was in Paris when the students'}

Participants in last week's clashes between French university students and the police were at a loss to explain how matters had got so out of hand. What was planned as a peaceful, silent, non-political protest on Thursday escalated into disturbances which, on Friday night, culminated in the death of the 22-year-old student Malik Oussekine. Certainly the Thursday demonstration was "politicized" by participants who, contrary to the organizers' appeals, brought political banners. But a high police profile at the march aggravated the situation. By Friday, the nationwide protests had taken on a frankly political tone, and on Saturday trades union leaders were being asked to sit in on the meetings of student delegates from all over France, and calls were going out for a one-day general strike.

The government's reactions - as so often in such situations - were too little, too late. The first, partial climb-down over the bill might have been effective on Thursday, before violence developed but it came only on Friday, a few hours before Oussekine's death. Security Minister Robert
Pandraud's statement, on Saturday, that if there had been "individual faults" on the part of the police, sanctions would be imposed, was coupled with a refusal to dissolve the special police 'anti-vandal' motorcycle squadds introduced early on Saturday morning.

Interestingly, by Saturday night, even students involved in the growing disorders were convinced that the genuine protests had been "manipulated", although opinions differed as to whether the alleged manipulators came from the extreme right or the extreme left.

From the beginning, there has been an emotional and in some degree irrational element in the students' and lycéens' opposition to what, viewed more logically, might have been seen as an unpleasant but necessary reform, given the current economic state of France and the problems of graduate unemployment. But lycée scholars have grown up considering it an inalienable right that all school leavers who pass the baccalaureat can automatically go to university, while restrictions on choice and combinations of subjects, and the pos-

\section{atience ran out}

sible development of a hierarchy of excellence among the universities, seemed a direct affront to liberty, equality and fraternity. Some students, too, seem to have been stung into their decision to take part in the demonstrations by the accusation, voiced on French television only a couple of weeks before by Daniel Cohn-Bendit, the 1968 student leader, that the present generation of French students are "apolitical'.

In reality, as several university lecturers have been at pains to point out, the hierarchical principle has long been established de facto in France, with prospective employers at least as interested in where an applicant studied as in his or her subject and academic record. The new law, they said, would simply validate the existing system. But as early as Friday afternoon, and particularly since the death of Oussekine, these same lecturers began privately to adopt a different stance. "I do not know whether I am on the side of the students over the law", one said, "but I am certainly not on the side of the police against the students!"

Vera Rich 